\title{
Immunoxpression of MMPs -9, -13 and TIMP-3 after Using Etch-and-rinse Adhesive
}

\author{
Imunoexpressão da MMP-9, MMP-13 e TIMP-3 após o Uso de Sistema Adesivo Convencional \\ Inmunoexpresión de MMP-9, MMP-13 y TIMP-3 tras el Uso de un Sistema Adhesivo Convencional
}

Received: 06/16/2021 | Reviewed: 06/28/2021 | Accept: 07/13/2021 | Published: 07/19/2021

Laís Maciel Costa

ORCID: https://orcid.org/0000-0003-3880-1914

University of Pernambuco, Brazil

E-mail: lasmc1989@gmail.com

Ariela Vilela Rizuto

ORCID: https://orcid.org/0000-0002-4664-4843

University of Pernambuco, Brazil

E-mail: arizuto@hotmail.com

Luciana Sarmento de Mendonça

ORCID: https://orcid.org/0000-0001-9468-878X

University of Pernambuco, Brazil

E-mail: lucianasarmento@yahoo.com.br

Marianne de Vasconcelos Carvalho

ORCID: https://orcid.org/0000-0002-6815-5696

University of Pernambuco, Brazil

E-mail: mariannecarvalho@gmail.com

Márcia Maria Fonseca da Silveira

ORCID: https://orcid.org/0000-0002-2611-5661

University of Pernambuco, Brazil

E-mail: marcia.silveira@upe.br

Ana Paula Veras Sobral

ORCID: https://orcid.org/0000-0002-0801-9385

University of Pernambuco, Brazil

E-mail: anapvsobral@yahoo.com.br

\begin{abstract}
The aim of the present study was to determine the expression of MMP-9, MMP-13 and TIMP-3 after using the XP Bond TM (Dentsply) dentin-bonding agent on 21 human teeth. Class I deep cavities were prepared and restored. After $01,07,14,21,30,90$ and 120 days, the teeth were extracted and processed for an immunohistochemical assessment $(\mathrm{n}=3)$. Immunohistochemical staining was performed using the monoclonal antibody anti-MMP-9, and polyclonal antibodies anti-MMP-13 and anti-TIMP-3. The immunoreactivity of metalloproteinases 9 and 13 was considered intense and moderate in the first storage intervals, before decreasing over time. In contrast, the immunoreactivity of TIMP-3 was considered absent in dentin and weak in pulp in the first time intervals, and completely absent in the subsequent intervals. MMP-9 expression in dentin and in pulp was prevalent in the dentinal tubules and odontoblastic layer, respectively. MMP-13 expression in dentin and in pulp was predominant in the pre-dentine region and odontoblastic layer, respectively. TIMP-3 expression was absent in dentin and predominantly located in the odontoblastic layer for pulp. In conclusion, the expression patterns of MMP-9, MMP-13 and TIMP-3 altered in the different time intervals studied. The increased expression of TIMP-3 in the first time intervals could suggest a synchronous response to the increased expression of MMPs in the same periods. The results confirmed the low performance of TIMP-3 in the physiological processes of the pulp-dentin complex for the conditions and materials tested herein.
\end{abstract}

Keywords: Dentin; Matrix metalloproteinase 9; Matrix metalloproteinase 13; Tissue inhibitor of metalloproteinase-3; Dentin-bonding agents.

\section{Resumo}

O objetivo do presente estudo foi avaliar a imunoexpressão da MMP-9, MMP-13 e TIMP-3 após o uso de sistema adesivo XP Bond ${ }^{\mathrm{TM}}$ (Dentsply) em 21 molares humanos. Cavidades classe I profundas foram preparadas e restauradas. Depois de 01, 07, 14, 21, 30, 90 e 120 dias, os dentes foram extraídos e processados para avaliação imuno-histoquímica $(n=3)$. A técnica imuno-histoquímica foi realizada utilizando-se o anticorpo monoclonal antiMMP-9, e policlonais anti-MMP-13 e anti-TIMP-3. A imunoexpressão das MMPs 9 e 13 foi considerada intensa e moderada, respectivamente, nos intervalos de 01 e 07 dias, com menor expressão nos intervalos subsequentes. Em contrapartida, a imunoexpressão do TIMP-3 foi considerada ausente em dentina e leve em polpa nos primeiros intervalos de tempo e ausente em dentina e polpa nos intervalos posteriores. A expressão da MMP-9 em dentina foi predominante nos canalículos dentinários e; em polpa, nos odontoblastos. A expressão da MMP-13 em dentina teve 
localização predominante na região de pré-dentina e; em polpa, nos odontoblastos. A expressão de TIMP-3 foi ausente em dentina e; em polpa, teve localização predominante nos odontoblastos. Conclui-se que o padrão de expressão das MMP-9, MMP-13 e do TIMP-3 sofre alteração nos diferentes intervalos de tempo estudados. O aumento de expressão do TIMP-3 nos primeiros intervalos de tempo pode demonstrar uma resposta ao simultâneo aumento da expressão das MMPs nos mesmos períodos. Os resultados evidenciaram a pouca expressão do TIMP-3 no complexo dentinopulpar para as condições e materiais testados.

Palavras-chave: Dentina; Metaloproteinase 9 da matriz; Metaloproteinase 13 da matriz; Inibidor tecidual de metaloproteinase-3; Adesivos dentinários.

\section{Resumen}

El presente estudio tenía como objetivo evaluar la inmunoexpresión de la MMP-9, MMP-13 y TIMP-3 después del uso de sistema adhesivo XP Bond ${ }^{\mathrm{TM}}$ (Dentsply) en 21 molares humanos. Cavidades profundas de clase I fueron preparadas y restauradas. Después de 01, 07, 14, 21, 30, 90 y 120 días, los dientes fueron extraídos y procesados para evaluación inmunohistoquímica $(n=3)$. La técnica inmunohistoquímica fue realizada utilizando lo anticuerpo monoclonal anti-MMP-9, y policlonales anti-MMP-13 y anti-TIMP-3. La inmunoexpresión de MMPs 9 y 13 fue considerada intensa y moderada en los intervalos de 01 y 07 días, con menor expresión en los intervalos subsecuentes. En cambio, la inmunoexpresión de TIMP-3 se consideró ausente en dentina y ligera en pulpa en los primeros intervalos de tiempo y ausente en dentina y pulpa en los intervalos posteriores. La expresión de MMP-9 en dentina fue predominante en canales dentinarios y; en pulpa, en odontoblastos. La expresión de MMP-13 en dentina se localizó en la región predentinaria y; en pulpa, en los odontoblastos. La expresión de TIMP-3 estaba ausente en dentina y, en pulpa, se localizaba predominantemente en los odontoblastos. Concluimos que el patrón de expresión de MMP-9, MMP-13 y TIMP-3 está alterado en los diferentes intervalos de tiempo estudiados. El aumento de la expresión de TIMP-3 en los primeros intervalos de tiempo puede demostrar una respuesta al aumento simultáneo de la expresión de las MMPs en los mismos períodos. Los resultados mostraron la baja expresión de TIMP-3 en el complejo dentinopulpar para las condiciones y materiales probados.
\end{abstract}

Palabras clave: Dentina; Metaloproteinasa 9 de la matriz; Metaloproteinasa 13 de la matriz; Inhibidor tisular de metaloproteinasa-3; Recubrimientos dentinarios.

\title{
1. Introduction
}

During the restorative procedure, the pulp responds to various forms of aggression, which result from cavity preparation and the toxic elements present in restorative materials, particularly dentin bonding agents (Lovász et al. 2021; Masioli et al. 2007). Chemical mediators such as cytokines and tumor necrosis factor $\alpha$ (TNF- $\alpha$ ), released during inflammatory responses, may activate the enzymes responsible for remodeling and degradation of the extracellular matrix (ECM) (Tahmiscija et al. 2019; Nagase et al. 2006).

ECM degrading enzymes, more commonly known as metalloproteinases (MMPs) (Visse \& Nagase 2003), are endopeptidases, which are calcium and zinc-dependent and are responsible for the degradation of virtually all components of the ECM and basement membrane proteins (Sabatini \& Pashley 2014; Franco et al. 2009). Evidence suggests that MMPs found in the dentin matrix or saliva can be responsible for the degradation of the exposed dentin organic matrix through acid demineralization produced by bacteria (Loreto et al. 2014). They may also be involved in the degradation of collagen fibrils (Li et al. 2015) which are not completely infiltrated by resin monomers from the adhesive system used in the dentin bonding technique (Tahmiscija et al. 2019; Nassar et al. 2014; Pashley et al. 2004).

The most studied MMPs in the oral cavity are MMP-8, MMP-2, MMP-9, and MMP-20 (Mazzoni et al. 2011). Recent studies have also indicated the involvement of MMP-13 (collagenase-3) in the development and progression of dental tissue disorders; however, data regarding its presence and activity are still scarce and must be better elucidated (Loreto et al. 2014). MMP-9 is predominantly found in the dentin matrix (Sabatini \& Pashley 2014) and appears to be closely associated with pathological pulp processes (Accorsi-Mendonca et al. 2013).

The activation of these enzymes appears to be associated with alterations in $\mathrm{pH}$, increase in temperature, and the presence of growth factors, cytokines, chemical agents, physical stress, compounds containing gold or mercury, detergent, oxidation, or other MMPs (Li et al. 2015; Khokha et al. 2013; Zitka et al. 2010). MMPs are regulated through the following 
mechanisms: binding to their specific substrates, precursor zymogen activation, the transcriptional capacity of the secretory cell, proteolytic degradation, non-specific endogenous inhibitors, and tissue inhibitors of MMPs (TIMPs) (Brew \& Nagase 2010; Nagase et al. 2006; Gomis-Ruth et al. 1997).

TIMPs are endogenous macromolecules capable of interfering with the cleavage of the catalytically active portion of the MMPs and/or converting the inactive MMPs (zymogens) to their active forms, thereby generating a positive or negative regulation, depending on the MMP-TIMP complex formed (Franco et al. 2009). TIMP-3 is the only subclass of TIMPs that can inhibit a range of MMPs (Brew \& Nagase 2010) and can be detected in the pulp tissue and odontoblastic cells (Sulkala et al. 2002).

The balance between MMPs and their tissue inhibitors dictates the rate of remodeling and degradation of the ECM (Hemmann et al. 2007; Nagase et al. 2006). Consequently, both MMPs and TIMPs can be considered markers for assessing the biocompatibility of restorative materials placed in close contact with the pulp-dentin complex. However, little is known about the association between these markers and the progression of the inflammatory processes. The absence/presence and intensities of MMPs and TIMPs can predict and extrapolate the molecular cascade during a minimal inflammatory process triggered during an adhesive restorative procedure until complete remission is achieved. Therefore, the present study aimed to evaluate the expressions of MMP-9, MMP-13, and TIMP-3 after using a total-etch system on human teeth at different time intervals.

\section{Methodology}

A longitudinal, descriptive, and observational study was consisting of two stages was conducted. The first stage was classified as the interventional or experimental study since it was carried out by the investigator in a specific group of people, in which the participants were the volunteers (Estrela 2001). The second stage was laboratorial, and histologic sections were performed with a thickness of $3 \mu \mathrm{m}$ to execute the immunohistochemical technique. Finally, the immunohistochemical technique was chosen for the present study because of its high reliability, which favors the specific identification of antigenic substances in the tissues. The primary advantages of immunohistochemical staining used in this study include the possibility to accurately analyze the distribution and composition of specific molecules, as well as the location of the function in situ.

\section{Clinical procedures}

The present study was approved by the Ethics Committee of the University of Pernambuco (protocol No. 297/09). Both male and female participants, (age range, 20-40 years) with indications for the extraction of mandibular or maxillary third molars under local anesthesia were included in the present study. All selected participants signed a statement of informed consent.

The inclusion criteria for the participants were as follows: fully erupted and healthy teeth, vital teeth with complete root formation, and no alterations in the alveolar bone. The exclusion criteria for the participants were as follows: systemic or oral diseases; syndromes involving ectodermal and mesodermal capsules a history of tooth attrition, abrasion, abfraction, and erosion, teeth with carious lesions, restorations, or a negative response to heat or cold in the pulp sensitivity test, and teeth with periodontal abnormalities (pericoronitis, periodontitis, and periodontal pocket) and root resorption. These criteria led to a sample of 21 teeth. The subjects were randomized into seven groups $(n=3)$.

Two radiographs were taken for each tooth: periapical, to analyze the root apex and alveolar bone, and bitewing to rule out the presence of caries. The third molar was anesthetized using a regional block or infiltrated with $2 \%$ mepivacaine with adrenalin (Mepiadre ${ }^{\circledR}$ - Nova DFL, Rio de Janeiro, Brazil). Dental prophylaxis was performed with pumice, water, and a brush before cavity preparation. 
The distance from the occlusal surface to the pulp chamber was measured using bitewing radiographs and a millimeter ruler. Class I cavities were prepared with a high-speed handpiece under water cooling with a \# 245 carbide bur (replaced after each preparation to avoid excessive heating). The cavity was approximately $1.5 \mathrm{~mm}$ deep from the roof of the pulp chamber. When the preparation was complete, a new interproximal radiograph was obtained to confirm the depth reached.

The bonding agent used was XP Bond, a conventional adhesive, involving an etching technique with 37\% phosphoric acid before the adhesive application from a single bottle (primer and adhesive together). The bonding procedures were performed according to the manufacturer's instructions (Table 1).

Table 1: Composition and specifications of the material tested in this study.

\begin{tabular}{llll}
\hline Material & Classification & $\begin{array}{l}\text { Manufacturers' } \\
\text { instructions }\end{array}$ & Composition \\
\hline XP Bond $^{\text {TM a }}$ & Total-etch dental & 1. Apply etching acid for & Carboxylic acid modified dimethacrylate \\
adhesive system & 15 seconds. & (TCB resin); Phosphoric acid modified \\
& 2. Wash etching acid for & acrylate resin (PENTA); \\
& 15 seconds. & Urethane Dimethacrylate (UDMA); \\
& 3. Remove excess water. & Triethyleneglycol dimethacrylate \\
& 4. Apply adhesive and let & (TEGDMA); 2-hydroxyethylmethacrylate \\
& act for & (HEMA); Butylated benzenediol \\
& 20 seconds. & (stabilizer); Ethyl-4- \\
& 5. Apply air gently to & dimethylaminobenzoate; \\
& evaporate & Camphorquinone; \\
& solvent. & Functionalized amorphous silica; t- \\
& 6. Light-cure for 10-20 & butanol \\
& seconds. & \\
& 7. Apply restorative & \\
material. & \\
\hline
\end{tabular}

Source: Authors.

The cavities were restored with Filtek Z250 A3 (3M ESPE Dental Products, St. Paul, MN, USA) in 2 mm increments. Final occlusal adjustments were made using a flame-shaped finishing diamond bur \#3118F (KG Sorensen, São Paulo, SP, Brazil). Finishing and polishing were performed with abrasive silicone polishing tips (Optimize, TDV Dental, Pomedore, SC, Brazil) and a diamond-impregnated polishing brush (Jiffy Brush, Ultradent Products, South Jordan, UT) after 48 h. Each patient was instructed to contact the researcher in events of sensitivity.

After the restorative procedure, the patients were randomly assigned to different time intervals for the performance of the extractions using a single-blinded envelope. Three specimens were taken at intervals of 1, 7, 14, 21, 30, 90, and 120 days. Teeth extractions were performed at pre-established intervals using forceps to minimize trauma. Thereafter, the apical thirds of the roots were immediately excised with a sterilized \#1065 diamond bur. These were done under an intensive water/air spray to allow the penetration of the fixative solution. The specimens were then immersed in a $10 \%$ formaldehyde solution.

\section{Laboratory procedure}

The teeth were demineralized using 5\% nitric acid. The specimens were then processed and embedded in paraffin. Semi-serial sections with $3 \mu \mathrm{m}$ thicknesses were obtained using a microtome (Leica RM 2125, Leica Microsystems, Nussloch $\mathrm{GmbH}$, Germany).

Immunohistochemical staining was performed using streptavidin-biotin-optimized peroxidase, a labeled streptavidinbiotin amplification system (LSAB - Dako, Glostrup, Denmark) and the monoclonal antibody anti-MMP-9, polyclonal antibodies anti-MMP-13 and anti-TIMP-3, with diaminobenzidine as the chromogen. 
After immunohistochemical processing, the specimens were incubated with the primary antibody, according to the specifications in Table 2.

Table 2: Clone, specificity, source, dilution, incubation and antigen retrieval of primary antibodies anti-MMP-9, anti-MMP-13 and anti-TIMP-3.

\begin{tabular}{lllllll}
\hline Clone & Specificity & Source & Dilution & Incubation & Antigen retrieval & \\
\hline 2C3 & MMP-9 & DBS & $1: 125$ & $60^{\prime}$ & $\begin{array}{l}\text { Pressure Cooking } \\
\text { Buffer (pH=6.0) }\end{array}$ & Citrate \\
\hline 181-15A12 & MMP-13 & Abcam & $1: 200$ & 60 & $\begin{array}{l}\text { Pressure Cooking } \\
\text { Buffer (pH=6.0) }\end{array}$ & Citrate \\
\hline $\begin{array}{l}\text { MM0036- } \\
\text { 7D3 }\end{array}$ & TIMP-3 & Abcam & $1: 50$ & 60 & Pressure Cooking / Citrate \\
\hline
\end{tabular}

Source: Authors.

Two blind examiners with experience in immunohistochemical analysis using conventional light microscopy $(10 X / 40 X / 100 X)$ analyzed all slides. A third researcher resolved the disagreements regarding the criteria. The immunostaining was examined considering the following histological features: type of immunopositive cell, tissue location (focal or diffuse), and intensity of immunostaining. The immunostaining pattern was classified as positive $(+)$ or negative $(-)$. Positive cases were also classified quantitatively according to the intensity of the marking: weak $(+)$, moderate $(++)$, and intense $(+++)$. Subsequently, a marking score as a percentage of positive cells was assigned as follows: score 0 , no positive cell; score $1,1 \%-$ $25 \%$ positive cells; score $2,25 \%-50 \%$ positive cells; and score $3,>50 \%$ of positive cells.

In the negative control slides, the primary antibody was replaced by immunoglobulin $\mathrm{G}$ ( $\operatorname{IgG})$. In the positive control slides, breast carcinoma for MMP-9 and MMP-13 and the placenta for TIMP-3 were used.

\section{Results}

Tables 3, 4, and 5 display the results of immunostaining, based on the groups and time intervals. 
Table 3: Immunostaining pattern of MMP-9 at different time intervals and dental substrates.

\begin{tabular}{|c|c|c|c|c|c|c|}
\hline Antibody/ Time interval & \multicolumn{6}{|c|}{ Specimens } \\
\hline & 1 & 2 & 3 & 1 & 2 & 3 \\
\hline & \multicolumn{3}{|c|}{ Dentin } & \multicolumn{3}{|c|}{ Pulp } \\
\hline $\begin{array}{l}\text { MMP-9 } \\
\text { 01 day }\end{array}$ & $\begin{array}{c}+++/ \\
\text { Score 3/ } \\
\text { Focal }\end{array}$ & $\begin{array}{c}+++/ \\
\text { Score 3/ } \\
\text { Focal }\end{array}$ & $\begin{array}{c}++/ \\
\text { Score 2/ } \\
\text { Focal }\end{array}$ & $\begin{array}{c}++/ \\
\text { Score 3/ } \\
\text { Focal }\end{array}$ & $\begin{array}{c}+++/ \\
\text { Score 3/ } \\
\text { Focal }\end{array}$ & $\begin{array}{c}+++/ \\
\text { Score 3/ } \\
\text { Focal }\end{array}$ \\
\hline days & $\begin{array}{c}+++/ \\
\text { Score 3/ } \\
\text { Focal }\end{array}$ & $\begin{array}{c}+++/ \\
\text { Score 3/ } \\
\text { Focal }\end{array}$ & $\begin{array}{c}+++/ \\
\text { Score 3/ } \\
\text { Focal }\end{array}$ & $\begin{array}{c}+++/ \\
\text { Score 3/ } \\
\text { Focal }\end{array}$ & $\begin{array}{c}+++/ \\
\text { Score } 3 / \\
\text { Focal }\end{array}$ & $\begin{array}{c}+++/ \\
\text { Score 3/ } \\
\text { Focal }\end{array}$ \\
\hline days & $\begin{array}{c}++/ \\
\text { Score 2/ } \\
\text { Focal }\end{array}$ & $\begin{array}{c}++/ \\
\text { Score 2/ } \\
\text { Focal }\end{array}$ & $\begin{array}{c}++/ \\
\text { Score 2/ } \\
\text { Focal }\end{array}$ & $\begin{array}{c}++/ \\
\text { Score 2/ } \\
\text { Focal }\end{array}$ & $\begin{array}{c}++/ \\
\text { Score 2/ } \\
\text { Focal }\end{array}$ & $\begin{array}{c}++/ \\
\text { Score 2/ } \\
\text { Focal }\end{array}$ \\
\hline days & $\begin{array}{c}+/ \\
\text { Score 2/ } \\
\text { Focal } \\
\end{array}$ & $\begin{array}{c}++/ \\
\text { Score 2/ } \\
\text { Focal } \\
\end{array}$ & $\begin{array}{c}++/ \\
\text { Score } 2 / \\
\text { Focal } \\
\end{array}$ & $\begin{array}{c}+/ \\
\text { Score 2/ } \\
\text { Focal } \\
\end{array}$ & $\begin{array}{c}+/ \\
\text { Score 2/ } \\
\text { Focal } \\
\end{array}$ & $\begin{array}{c}+/ \\
\text { Score 2/ } \\
\text { Focal }\end{array}$ \\
\hline days & $\begin{array}{c}++/ \\
\text { Score 2/ } \\
\text { Focal }\end{array}$ & $\begin{array}{c}++/ \\
\text { Score 2/ } \\
\text { Focal }\end{array}$ & $\begin{array}{c}++/ \\
\text { Score 2/ } \\
\text { Focal }\end{array}$ & $\begin{array}{c}++/ \\
\text { Score 2/ } \\
\text { Focal }\end{array}$ & $\begin{array}{c}++/ \\
\text { Score 2/ } \\
\text { Focal }\end{array}$ & $\begin{array}{c}++/ \\
\text { Score 2/ } \\
\text { Focal }\end{array}$ \\
\hline days & $\begin{array}{c}++/ \\
\text { Score 2/ } \\
\text { Focal } \\
\end{array}$ & $\begin{array}{c}++/ \\
\text { Score 2/ } \\
\text { Focal } \\
\end{array}$ & $\begin{array}{c}++/ \\
\text { Score } 2 / \\
\text { Focal } \\
\end{array}$ & $\begin{array}{c}++/ \\
\text { Score } 2 / \\
\text { Focal } \\
\end{array}$ & $\begin{array}{c}++/ \\
\text { Score 2/ } \\
\text { Focal } \\
\end{array}$ & $\begin{array}{c}++/ \\
\text { Score 2/ } \\
\text { Focal }\end{array}$ \\
\hline days & $\begin{array}{c}++/ \\
\text { Score 2/ } \\
\text { Focal }\end{array}$ & $\begin{array}{c}++/ \\
\text { Score 2/ } \\
\text { Focal }\end{array}$ & $\begin{array}{c}++/ \\
\text { Score 2/ } \\
\text { Focal }\end{array}$ & $\begin{array}{c}++/ \\
\text { Score 2/ } \\
\text { Focal }\end{array}$ & $\begin{array}{c}++/ \\
\text { Score 2/ } \\
\text { Focal }\end{array}$ & $\begin{array}{c}++/ \\
\text { Score 2/ } \\
\text { Focal }\end{array}$ \\
\hline
\end{tabular}

Source: Authors.

Table 4: Immunostaining pattern of MMP-13 at different time intervals and dental substrates.

\begin{tabular}{|c|c|c|c|c|c|c|}
\hline \multirow{3}{*}{$\begin{array}{l}\text { Antibody/ Time } \\
\text { interval }\end{array}$} & \multicolumn{6}{|c|}{ Specimens } \\
\hline & 1 & 2 & 3 & 1 & 2 & 3 \\
\hline & \multicolumn{3}{|c|}{ Dentin } & \multicolumn{3}{|c|}{ Pulp } \\
\hline $\begin{array}{l}\text { MMP-13 } \\
\text { 01 day }\end{array}$ & $\begin{array}{c}++/ \\
\text { Score 2/ } \\
\text { Focal }\end{array}$ & $\begin{array}{c}++/ \\
\text { Score 2/ } \\
\text { Focal }\end{array}$ & $\begin{array}{c}++/ \\
\text { Score 2/ } \\
\text { Focal }\end{array}$ & $\begin{array}{c}++/ \\
\text { Score 2/ } \\
\text { Focal }\end{array}$ & $\begin{array}{c}++/ \\
\text { Score 2/ } \\
\text { Focal }\end{array}$ & $\begin{array}{c}++/ \\
\text { Score 2/ } \\
\text { Focal }\end{array}$ \\
\hline 07 days & $\begin{array}{c}++/ \\
\text { Score 2/ } \\
\text { Focal } \\
\end{array}$ & $\begin{array}{c}++/ \\
\text { Score 2/ } \\
\text { Focal } \\
\end{array}$ & $\begin{array}{c}++/ \\
\text { Score 2/ } \\
\text { Focal } \\
\end{array}$ & $\begin{array}{c}++/ \\
\text { Score 2/ } \\
\text { Focal } \\
\end{array}$ & $\begin{array}{c}++/ \\
\text { Score 2/ } \\
\text { Focal } \\
\end{array}$ & $\begin{array}{c}++/ \\
\text { Score 2/ } \\
\text { Focal } \\
\end{array}$ \\
\hline 14 days & $\begin{array}{c}++/ \\
\text { Score 2/ } \\
\text { Focal } \\
\end{array}$ & $\begin{array}{c}+/ \\
\text { Score 2/ } \\
\text { Focal } \\
\end{array}$ & $\begin{array}{c}++/ \\
\text { Score 2/ } \\
\text { Focal } \\
\end{array}$ & $\begin{array}{c}+/ \\
\text { Score 1/ } \\
\text { Focal } \\
\end{array}$ & $\begin{array}{c}+/ \\
\text { Score 1/ } \\
\text { Focal } \\
\end{array}$ & $\begin{array}{c}+ \\
\text { Score 1/ } \\
\text { Focal } \\
\end{array}$ \\
\hline 21 days & $\begin{array}{c}-/ \\
\text { Score } 0\end{array}$ & $\begin{array}{c}-/ \\
\text { Score } 0\end{array}$ & $\begin{array}{c}-/ \\
\text { Score } 0\end{array}$ & $\begin{array}{c}+/ \\
\text { Score 1/ } \\
\text { Focal } \\
\end{array}$ & $\begin{array}{c}+/ \\
\text { Score 1/ } \\
\text { Focal } \\
\end{array}$ & $\begin{array}{c}+/ \\
\text { Score 1/ } \\
\text { Focal } \\
\end{array}$ \\
\hline 30 days & $\begin{array}{c}-/ \\
\text { Score } 0\end{array}$ & $\begin{array}{c}-/ \\
\text { Score } 0\end{array}$ & $\begin{array}{c}-/ \\
\text { Score } 0\end{array}$ & $\begin{array}{c}+ \\
\text { Score 1/ } \\
\text { Focal } \\
\end{array}$ & $\begin{array}{c}+/ \\
\text { Score 1/ } \\
\text { Focal } \\
\end{array}$ & $\begin{array}{c}+/ \\
\text { Score 1/ } \\
\text { Focal } \\
\end{array}$ \\
\hline 90 days & $\begin{array}{c}-/ \\
\text { Score } 0\end{array}$ & $\begin{array}{c}-/ \\
\text { Score } 0\end{array}$ & $\begin{array}{c}-/ \\
\text { Score } 0\end{array}$ & $\begin{array}{c}+/ \\
\text { Score 1/ } \\
\text { Focal } \\
\end{array}$ & $\begin{array}{c}+/ \\
\text { Score 1/ } \\
\text { Focal } \\
\end{array}$ & $\begin{array}{c}+/ \\
\text { Score 1/ } \\
\text { Focal } \\
\end{array}$ \\
\hline 120 days & $\begin{array}{c}-/ \\
\text { Score } 0\end{array}$ & $\begin{array}{c}-/ \\
\text { Score } 0\end{array}$ & $\begin{array}{c}-/ \\
\text { Score } 0\end{array}$ & $\begin{array}{c}+ \\
\text { Score 1/ } \\
\text { Focal } \\
\end{array}$ & $\begin{array}{c}+/ \\
\text { Score 1/ } \\
\text { Focal } \\
\end{array}$ & $\begin{array}{c}+/ \\
\text { Score 1/ } \\
\text { Focal } \\
\end{array}$ \\
\hline
\end{tabular}


Table 5: Immunostaining pattern of TIMP-3 at different time intervals and dental substrates.

\begin{tabular}{|c|c|c|c|c|c|c|}
\hline \multirow{3}{*}{$\begin{array}{l}\text { Antibody/ Time } \\
\text { interval }\end{array}$} & \multicolumn{6}{|c|}{ Specimens } \\
\hline & 1 & 2 & 3 & 1 & 2 & 3 \\
\hline & \multicolumn{3}{|c|}{ Dentin } & \multicolumn{3}{|c|}{ Pulp } \\
\hline TIMP-3 & -1 & $-/$ & -1 & +1 & +1 & +1 \\
\hline 01 day & Score 0 & Score 0 & Score 0 & $\begin{array}{l}\text { Score 1/ } \\
\text { Focal }\end{array}$ & $\begin{array}{c}\text { Score 1/ } \\
\text { Focal }\end{array}$ & $\begin{array}{c}\text { Score 1/ } \\
\text { Focal }\end{array}$ \\
\hline 07 days & $\begin{array}{c}-/ \\
\text { Score } 0\end{array}$ & $\begin{array}{c}-/ \\
\text { Score } 0\end{array}$ & $\begin{array}{c}-/ \\
\text { Score } 0\end{array}$ & $\begin{array}{c}+/ \\
\text { Score 1/ } \\
\text { Focal }\end{array}$ & $\begin{array}{c}+/ \\
\text { Score 1/ } \\
\text { Focal }\end{array}$ & $\begin{array}{c}+/ \\
\text { Score 1/ } \\
\text { Focal }\end{array}$ \\
\hline 14 days & $\begin{array}{c}-/ \\
\text { Score } 0\end{array}$ & $\begin{array}{c}-/ \\
\text { Score } 0\end{array}$ & $\begin{array}{c}-/ \\
\text { Score } 0\end{array}$ & $\begin{array}{c}+/ \\
\text { Score 1/ } \\
\text { Focal }\end{array}$ & $\begin{array}{c}+/ \\
\text { Score 1/ } \\
\text { Focal }\end{array}$ & $\begin{array}{c}+/ \\
\text { Score 1/ } \\
\text { Focal }\end{array}$ \\
\hline 21 days & $\begin{array}{c}-/ \\
\text { Score } 0\end{array}$ & $\begin{array}{c}-/ \\
\text { Score } 0\end{array}$ & $\begin{array}{c}-/ \\
\text { Score } 0\end{array}$ & $\begin{array}{c}+/ \\
\text { Score 1/ } \\
\text { Focal }\end{array}$ & $\begin{array}{c}+/ \\
\text { Score 1/ } \\
\text { Focal }\end{array}$ & $\begin{array}{c}+/ \\
\text { Score 1/ } \\
\text { Focal }\end{array}$ \\
\hline 30 days & $\begin{array}{c}-/ \\
\text { Score } 0\end{array}$ & $\begin{array}{c}-/ \\
\text { Score } 0\end{array}$ & $\begin{array}{c}-/ \\
\text { Score } 0\end{array}$ & $\begin{array}{c}-/ \\
\text { Score } 0\end{array}$ & $\begin{array}{c}-/ \\
\text { Score } 0\end{array}$ & $\begin{array}{c}-/ \\
\text { Score } 0\end{array}$ \\
\hline 90 days & $\begin{array}{c}-/ \\
\text { Score } 0\end{array}$ & $\begin{array}{c}-/ \\
\text { Score } 0\end{array}$ & $\begin{array}{c}-/ \\
\text { Score } 0\end{array}$ & $\begin{array}{c}-/ \\
\text { Score } 0\end{array}$ & $\begin{array}{c}-/ \\
\text { Score } 0\end{array}$ & $\begin{array}{c}-/ \\
\text { Score } 0\end{array}$ \\
\hline 120 days & $\begin{array}{c}-/ \\
\text { Score } 0\end{array}$ & $\begin{array}{c}-/ \\
\text { Score } 0\end{array}$ & $\begin{array}{c}-/ \\
\text { Score } 0\end{array}$ & $\begin{array}{c}-/ \\
\text { Score } 0\end{array}$ & $\begin{array}{c}-/ \\
\text { Score } 0\end{array}$ & $\begin{array}{c}-/ \\
\text { Score } 0\end{array}$ \\
\hline
\end{tabular}

Source: Authors.

The expression patterns of MMP-9, MMP-13 and TIMP-3 altered in the different time intervals studied. Immunoexpression results of MMP-9, MMP-13 and TIMP-3 can be exemplified in figures 1, 2 and 3 respectivally.

Figure 1: Intense and focal immunoexpression of MMP-9 (Score 3) located in the dentinal tubules (07-day group) (LSAB/IHC $100 \mathrm{X})$.

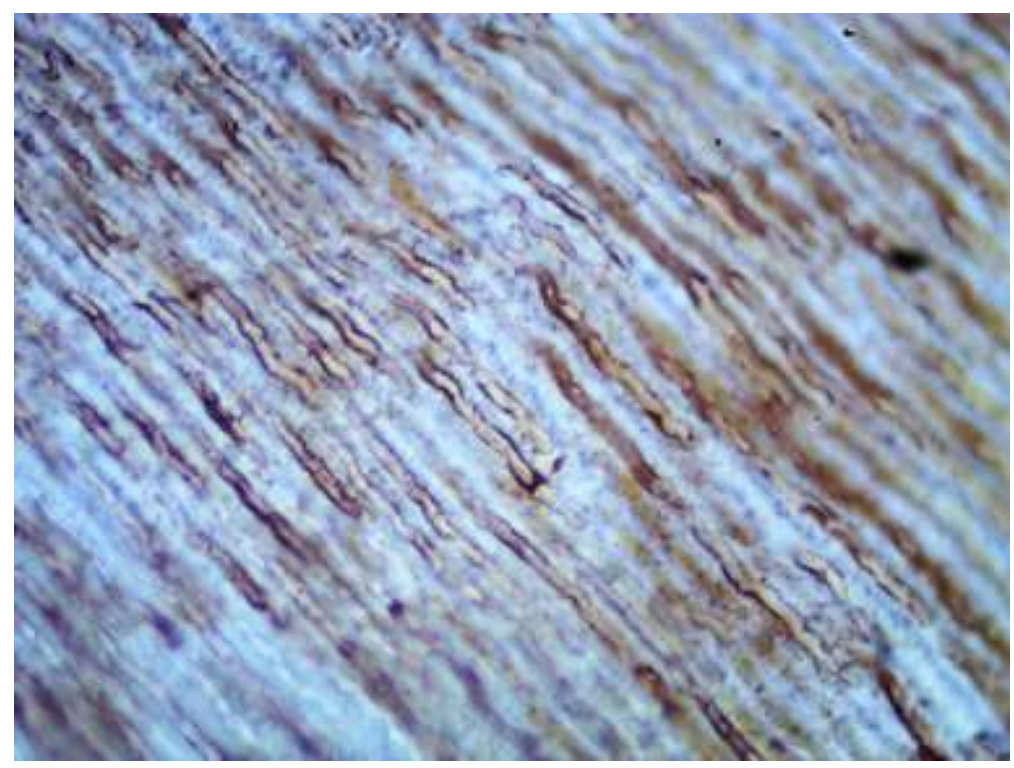

Source: Authors. 
The expression of MMP-9 in the dentin and pulp was predominantly observed in the dentinal tubules and odontoblastic layer, respectively (Figure 1). The 1-day and 7-day groups showed intense immunoexpression (score 3) in the pulp and dentin, except for one specimen in dentin that showed moderate expression (score 2). In the other groups, the expression was moderate (score 2). All specimens showed focal localization, as indicated in Figure 1.

Figure 2: Moderate and focal immunoexpression of MMP-13 (Score 2) located in the pre-dentine region (01-day group) (LSAB/IHC 40X).

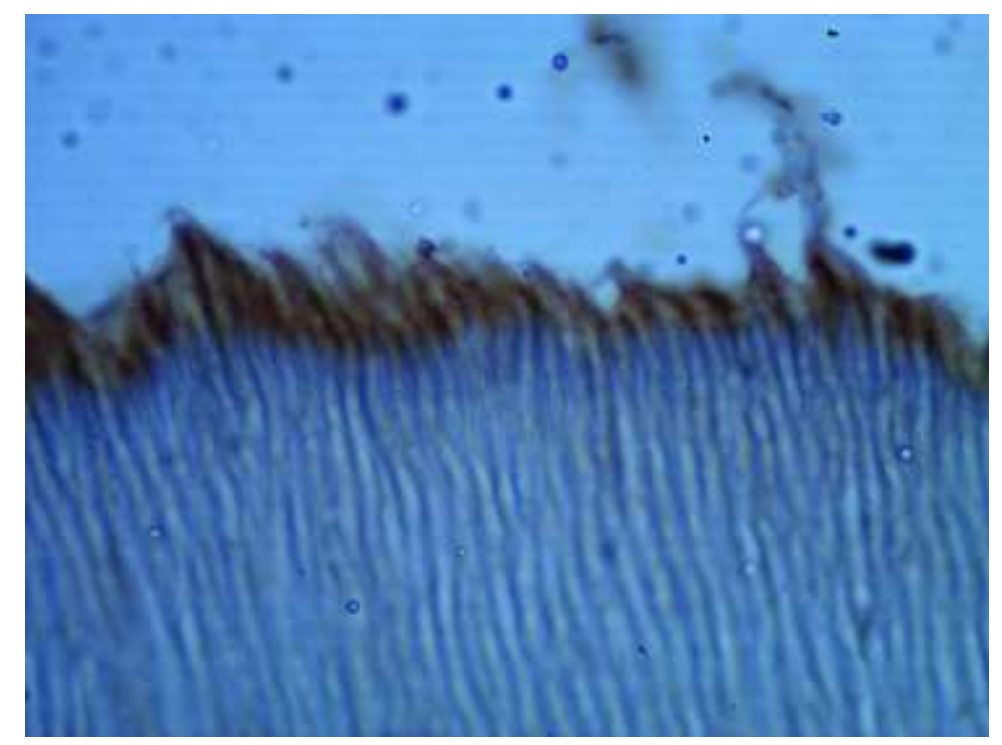

Source: Authors.

The expression of MMP-13 in the dentin and pulp was predominantly observed in the pre-dentin and odontoblastic layers, respectively (Figure 2). The 1-day and 7-day groups showed moderate immunoexpressions in the pulp and dentin (score 2), while the 14-day group showed moderate expression in the dentin (score 2) and weak expression in the pulp (score 1). In the other groups, the expression was weak in the pulp (score 1) and absent in the dentin (score 0). All immunopositive specimens showed focal localization, as indicated in Figure 2.

Figure 3: Weak and focal immunoexpression of TIMP-3 (Score 1) located in odontoblastic layer (07-day group) (LSAB/IHC $10 \mathrm{X})$.

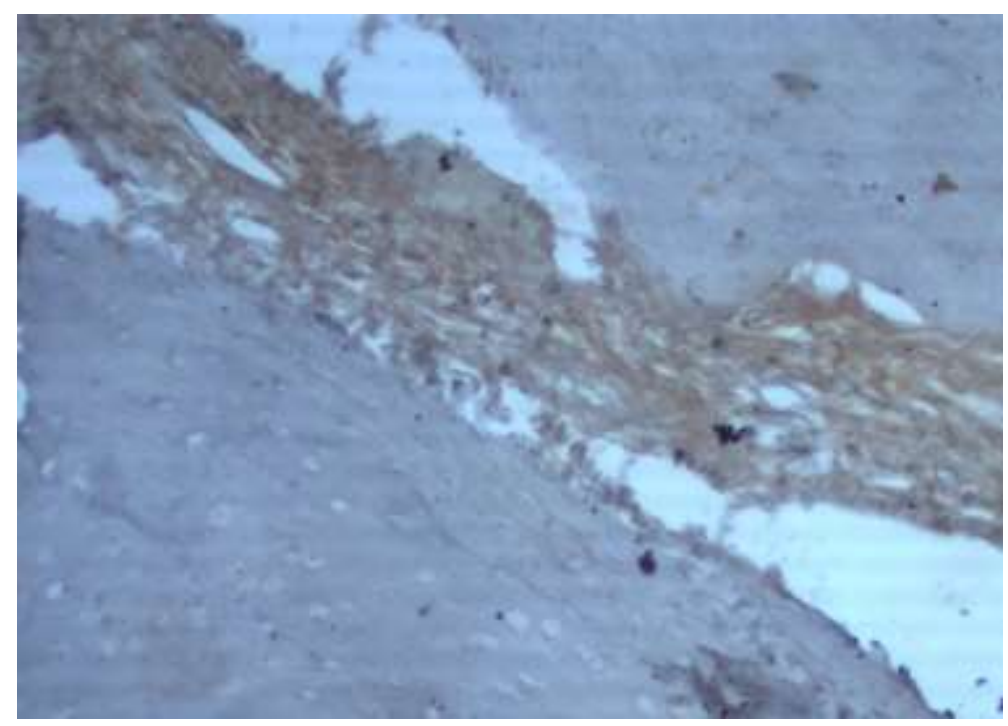

Source: Authors. 
The expression of TIMP-3 in the pulp was predominantly located in the odontoblastic layer (Figure 3). For all specimens and groups, TIMP-3 expression was absent in the dentin (score 0). In the pulp, the expressions were weak (score 1) for the 1-, 7-, 14-, and 21-day groups and absent for the 30-, 90-, and 120-day groups (score 0). All immunopositive specimens showed focal localization, as indicated in Figure 3.

\section{Discussion}

MMPs and their tissue inhibitors have been widely studied in the oral cavity to determine the absence, presence, and degree of intensity of protein activity for different restorative materials. However, their associations with the progression of the inflammatory processes and the capacity for pulp regeneration over time have not been studied and deserve special attention.

In our study, MMP-9 was expressed focally and intensely in the pulp and dentin of almost all specimens. This expression was characterized by its intensity in the initial time intervals of the experiment and decay over the observation period. It is clear from the literature that MMP-9 is commonly present in the pulp-dentin complex of healthy teeth (Lovász et al. 2021; Tahmiscija et al. 2019). However, Mazzoni et al. (2009) (2015) reported that MMP-9 can induce protein expression in the presence of external stimuli and chemicals released by restorative materials, such as acidic monomers (Lovász et al. 2021). These would explain the increased expression of this protein during the first period of observation in the present study. However, as they are cross-sectional studies, they do not provide a tail-and-effect relationship with the triggering of chemical reactions occurring in the pulp-dentin complex over the course of days.

During etching with 37\% phosphoric acid, the activation of MMPs occurs due to the low pH, resulting in cleavage of the pro-domain, thereby favoring the functional activity of MMPs. Mazzoni et al. (2009) studied the distribution and localization of MMP-9 in non-demineralized, partially demineralized, and completely demineralized dentins. In the partially and fully demineralized dentins, immunostaining was observed primarily in the intertubular dentin and dentinal tubules. Positive staining was observed in the non-demineralized dentin, although the intensity was lower than that in the demineralized specimens. These results support the hypothesis that MMP-9 is an inherent constituent of the dentin organic matrix, and its expression can be altered by conditioning agents.

However, recent studies have shown that activated MMPs are stable at low $\mathrm{pH}$ (produced during phosphoric acid etching), with improved activity in neutral values (Tezvergil-Mutluay et al. 2013). Therefore, resin monomers are mainly responsible for the "reactivation" of MMPs (Mazzoni et al. 2015). Furthermore, complete etching releases calcium and zinc ions, which are required for MMP activity (Sabatini \& Pashley 2014; Tezvergil-Mutluay et al. 2010).

Our study supports the fact that MMP-9 is the most prevalent form found in the dentin matrix (Sabatini \& Pashley 2014), particularly in the dentinal tubules. Mazzoni et al. (2009) examined the location and distribution of MMP-9 in the organic matrix of human dentin. The maximum expression of MMP-9 was observed in the intratubular dentin. In the present study, immunostaining of MMP-9 was also observed in regions of odontoblastic layers; the reason might be that most of the MMPs found in the pulp-dentin complex are produced and secreted by odontoblastic cells. These proteases are secreted by odontoblasts and remain inactive within the dentin ECM (Almahdy et al. 2012).

The time intervals in the present study were used to compare the expression of MMPs given the expected inflammation (acute and chronic) resulting from the aggression of the pulp-dentin complex, including cavity preparation, remaining dentin thickness, etching, and composition of the adhesive system. For MMP-9, the greatest intensity of expression was observed after 1 and 7 days, before decreasing and stabilizing in the subsequent intervals. Initially, the pulp-dentin complex triggers an inflammatory process against an aggressor agent involving dentinal fluid, odontoblasts, lymphocytes, neuropeptides, chemokines, and inflammatory cytokines (Hebling et al. 2010), with a consequent decrease in pH and higher activation of MMPs, as found in the present study. Subsequently, this inflammatory process tends to be resolved; however, if 
the intensity of the offending stimulus is high, pulp necrosis can occur (Hebling et al. 2010). Tahmiscija et al. (2019) observed a significant increase in MMP-9 expression in inflamed dental pulp compared to that in healthy subjects after immunohistochemical assay.

This study describes the presence and distribution of specific MMP-13 in human teeth after the use of a conventional dentin-bonding agent. MMP-13 was focally and moderately expressed in the dentin and pulp for all specimens in the 1- and 7day groups. In the 14-day group, focal and moderate expression was observed in dentin, while focal and weak expression was observed in the pulp. For the 21-, 30-, 90-, and 120-day groups, immunoexpression was considered focal and weak in the pulp and absent in the dentin. This result corroborated the reports of Hebling et al. (2010) on the continuity of pulp inflammation and the release of chemical mediators. The inflammatory response is considered the initial phase and part of the repair and regeneration of the pulp-dentin complex. This stage involves the inflammatory mediator release, a decrease in $\mathrm{pH}$, and an increase in the number of activated metalloproteinases. Based on the level and maintenance of inflammation, the response elicited can cause damage to the pulp tissue (De Souza Costa et al. 2014).

Loreto et al. (2014) analyzed the immunohistochemical expression of MMP-13 in carious and healthy teeth And observed that the immunoreactivity of MMP-13 appears to be associated with the progression of carious lesions. In healthy dentin, immunoreactivity was considered weak and confined to the peritubular region, unlike in the present study, in which immunoreactivity was confined to the pre-dentin region. This was probably because the pre-dentin is a region of gradual mineralization of the organic matrix and contains a higher amount of the specific substrate of MMP-13 (collagen type II). Knauper et al. (1997) reported that MMP-13 exhibits greater collagenolytic activity on type II collagen, but is five to six times less efficient in the hydrolysis of collagen type I or III.

This is the first study describing the presence and specific distribution of TIMP-3 in human teeth after the use of a conventional dentin bonding agent. TIMPs are involved in the local control of MMPs in tissues. However, according to Mazzoni et al. (2015), the inhibitory activity of TIMP may suffer as a result of certain factors, including acid attacks on dentin tissue, an increase in the amount of activated MMPs, and the presence of adhesive monomers.

Ishiguro et al. (1994) demonstrated that monomer resin acids could indeed inhibit TIMP-1. Thus, due to the structural similarities between TIMP-1 and TIMP-3, there may be an equivalent molecular response to contact with monomer resin acids, which would explain the results of this study. TIMP-3 was focally and mildly expressed in the pulp and dentin specimens of the 1-, 7-, 14- and 21-day groups and was considered absent in those of 30-, 90- and 120-day groups.

TIMP-3 has a higher inhibition spectrum compared to other TIMPs and remains strongly attached to the ECM, which limits its activity in areas close to its synthesis and deposition (Brew \& Nagase 2010; Brew et al. 2000). This would explain why TIMP-3 was only found in the odontoblastic layer in the present study.

Immune expression of TIMP-3 was absent in the pulp-dentin complex of the 30-day group. Possibly, the reduction of stimuli for the expression of tissue inhibitors, caused by the reduced immunoreactivity of MMPs, might have altered the molecular dynamics of TIMP-3 and reduced its immunoreactivity.

Given the results of the present study and others reported in the literature, a correlation between the expressions of MMP-9 and MMP-13 and biological events in the pulp-dentin complex (deep cavities) after the application of a conventional dentin bonding agent would be expected. Understanding the cellular response, the release of intrinsic chemical agents, and repercussions on the pulp-dentin complex during and after the adhesive restorative procedures is extremely critical because these factors can interfere with the success and longevity of the restoration, helping the clinician to choose the most adequate adhesive system and adopt intervention in each case. 


\section{Conclusion}

In conclusion, the expression patterns of MMP-9, MMP-13, and TIMP-3 were altered at different time intervals. Our results suggested that during a restorative procedure using the etch-and-rinse adhesive technique, there was a greater release of MMPs and TIMP studied in the first days after the restorative procedure, tending to decrease in the following days. The chemical release and consequent inflammatory response after using this technique could affect the longevity of restorations in deep cavities.

MMP-9 was expressed in all study groups, certifying its intrinsic character and its propensity for ECM degradation, including intratubular collagen poorly filled by the adhesive system. The increased expression of TIMP-3 in the initial time intervals suggested a synchronous response to the increased expression of MMPs in the same period. The results confirmed the low performance of TIMP-3 in the physiological processes of the pulp-dentin complex under the conditions and materials tested herein. Further studies are required to elucidate the specific role of TIMP-3 in molecular events in the pulp-dentin complex and to determine other mechanisms that might be linked to increased proteolytic degradation when in contact with restorative materials.

The use of the etch-and-rinse adhesive system XP Bond did not generate chronic MMP or TIMP immunoexpression, denoting a repair capacity and reversibility of the inflammatory process of the pulp-dentin complex against the aggression of the adhesive restorative procedure. Further longitudinal studies are needed to investigate other molecular markers present in the pulp-dentin complex and substances capable of decreasing the excess release of MMPs, contribute to the decrease in the pulp inflammatory response, and prevent the hybrid layer degradation.

\section{References}

Accorsi-Mendonça, T., Silva, E. J. N. L., Marcaccini, A. M., Gerlach, R. F., Duarte, K. M. R., Pardo, A. P. S., Line, S. R. P., \& Zaia, A. A. (2013). Evaluation of gelatinases, tissue inhibitor of matrix metalloproteinase-2, and myeloperoxidase protein in healthy and inflamed human dental pulp tissue. $J$ Endod, 39, $879-882$.

Brew, K., Dinakarpandian, D., \& Nagase, H. (2000). Tissue inhibitors of metalloproteinases: evolution, structure and function. Biochim Biophys Acta, 1477 (12), 267-283.

Brew, K., \& Nagase, H. (2010). The tissue inhibitors of metalloproteinases (TIMPs): An ancient family with structural and functional diversity. Biochim Biophys Acta, 1803(1), 55-71.

De Souza Costa, C. A., Hebling, J., Scheffel, D. L., Soares, D. G., Basso, F. G., \& Ribeiro, A. P. (2014). Methods to evaluate and strategies to improve the biocompatibility of dental materials and operative techniques. Dent Mater, 30(7), 769-784.

Estrela, C. (2001). Metodologia científica: ensino e pesquisa em odontologia. In Metodologia científica: ensino e pesquisa em odontologia (pp. 483-483).

Franco, C. F., Souza, A. C. D., Costa, J. E., \& D‘Almeida, P. M. (2009). MMP-8 and periodontal disease. R. Periodontia, 19(4), 51-60.

Gomis-Ruth, F. X., Maskos, K., Betz, M., Bergner, A., Huber, R., Suzuki, K., Yoshida, N., Nagase, H., Brew, K., Bourenkovk, G. P., Bartunikk, H., \& Bode, W. (1997). Mechanism of inhibition of the human matrix metalloproteinase stromelysin-1 by TIMP-1. Nature, 389(6646), 77-81.

Hebling, J., Ribeiro, A. P. D., \& Costa, C. A. S. (2010). Relationship between dental materials and the dentin-pulp complex. Rev Odontol Bras Central, 18(48), 1-9.

Hemmann, S., Graf, J., Roderfeld, M., \& Roeb, E. (2007). Expression of MMPs and TIMPs in liver fibrosis - a systematic review with special emphasis on anti-fibrotic strategies. J Hepatol, 46(5), 955-975.

Ishiguro, K., Yamashita, K., Nakagaki, H., Iwata, K., \& Hayakawa, T. (1994). Identification of tissue inhibitor of metalloproteinases-1 (TIMP-1) in human teeth and its distribution in cementum and dentine. Arch Oral Biol, 39(4), 345-349.

Khokha, R., Murthy, A., \& Weiss, A. (2013). Metalloproteinases and their natural inhibitors in inflammation and immunity. Nature, 13(9), 649-665.

Knauper, V., Cowell, S., Smith, B., Lopez-Otin, C., O'shea, M., Morris, H., Zardi, L., \& Murphy, G. (1997). The Role of the C-terminal Domain of Human Collagenase-3 (MMP-13) in the Activation of Procollagenase-3, Substrate Specificity, and Tissue Inhibitor of Metalloproteinase Interaction. J. Biol. Chem, 272(12), 7608-7616.

Li, H., Li, T., Li, X., Zhang, Z., Li, P., \& Li, Z. (2015) Morphological effects of MMPs inhibitors on the dentin bonding. Int J Clin Exp Med, 8(7), 1079310803. 
Loreto, C., Galanti, C., Musumeci, G., Rusu, M. C., \& Leonardi, R. (2014). Immunohistochemical analysis of matrix metalloproteinase-13 in human caries dentin. Eur J Histochem, 58(1), 47-51.

Lovász, B.V., Lempel, E., Szalma, J., Sétáló, G., Vecsernyés, M., \& Berta, G. (2021). Influence of TEGDMA monomer on MMP-2, MMP-8, and MMP-9 production and collagenase activity in pulp cells. Clinical Oral Investigations, 25(4), 2269-2279.

Masioli, M. A., Dias, K. R. H. C., Vargas, P. R. M., \& Rosa, R. (2007). Microscopic evaluation of exposed human pulp, following direct pulp capping with dentine adhesive and calcium hydroxide-based. UFES Rev. Odontol, 9(3), 4-11.

Mazzoni, A., Papa, V., Nato, F., Carrilho, M., Tjäderhane, L., Ruggeri Jr, A., Gobbi, P., Mazzotti, G., Tay, F. R., Pashley, D. H., \& Breschi, L. (2011). Immunohistochemical and biochemical assay of MMP-3 in human dentine. $J$ Dent, 39, 231-237.

Mazzoni, A., Carrilho, M., Papa, V., Tjäderhane, L., Gobbi, P., Nucci, C., \& Breschi, L. (2011). MMP-2 assay within the hybrid layer created by a two-step etch-and-rinse adhesive: biochemical and immunohistochemical analysis. Journal of Dentistry, 39(7), 470-477.

Mazzoni, A., Pashley, D. H., Tay, F. R., Gobbi, P., Orsini, G., Ruggeri Jr, A., \& Breschi, L. (2009). Immunohistochemical identification of MMP-2 and MMP-9 in human dentin: correlative FEI-SEM/TEM analysis. Journal of Biomedical Materials Research Part A: An Official Journal of The Society for Biomaterials, The Japanese Society for Biomaterials, and The Australian Society for Biomaterials and the Korean Society for Biomaterials, 88(3), 697-703.

Mazzoni, A., Tjäderhane, L., Checchi, V., Di Lenarda, R., Salo, T., Tay, F. R., \& Breschi, L. (2015). Role of dentin MMPs in caries progression and bond stability. Journal of dental research, 94(2), 241-251.

Nagase, H., Visse, R., \& Murphy, G. (2006). Structure and function of matrix metalloproteinases and TIMPs. Cardiovasc Res, 69(3), 562-573.

Nassar, M., Hiraishi, N., Shimokawa, H., Tamura, Y., Otsuki, M., Kasugai, S., Ohya, K., \& Tagami, J. (2014). The inhibition effect of non-protein thiols on dentinal matrix metalloproteinase activity and HEMA cytotoxicity. J Dent, 42(3), 312-318.

Pashley, D. H., Tay, F. R., Yiu, C., Hashimoto, M., Breschi, L., Carvalho, R. M., \& Ito, S. (2004). Collagen degradation by host-derived enzymes during aging. J Dent Res, 83(3), 216-221.

Sabatini, C., \& Pashley, D. H. (2014). Mechanisms Regulating the Degradation of Dentin Matrices by Endogenous Dentin Proteases and their Role in Dental Adhesion. A Review. Am J Dent, 27(4), 203-214.

Sulkala, M., Larmas, M., Sorsa, T., Salo, T., \& Tjäderhane, L. (2002). The localization of matrix metalloproteinase-20 (MMP-20, enamelysin) in mature human teeth. J Dent Res, 81(9), 603-607.

Tahmiščija, I., Radović, S., Jukić-Krmek, S., Konjhodžić, A., Hasić-Branković, L., Džanković, A., \& Korać, S. (2019). Immunohistochemical expression of matrix metalloproteinase MMP-2 and MMP-9 in healthy and inflamed human dental pulp. Folia Medica Facultatis Medicinae Universitatis Saraeviensis, 53(1), 3-9.

Tezvergil-Mutluay, A., Agee, K. A., Hoshika, T., Carrilho, M., Breschi, L., Tjäderhane, L., \& Pashley, D. H. (2010). The requirement of zinc and calcium ions for functional MMP activity in demineralized dentin matrices. Dental Materials, 26(11), 1059-1067.

Tezvergil-Mutluay, A., Mutluay, M., Seseogullari-Dirihan, R., Agee, K. A., Key, W. O., Scheffel, D. L. S., \& Pashley, D. H. (2013). Effect of phosphoric acid on the degradation of human dentin matrix. Journal of dental research, 92(1), 87-91.

Visse, R., \& Nagase, H. (2003). Matrix metalloproteinases and tissue inhibitors of metalloproteinases: structure, function, and biochemistry. Circ Res, 92, $827-839$.

Zitka, O., Kukacka, J., Krizkov, S., Huska, D., Adam, V., Masarik, M., Prusa, R., \& Kizek, R. (2010). Matrix Metalloproteinases. Curr Med Chem, 17(31), 3751-3768. 